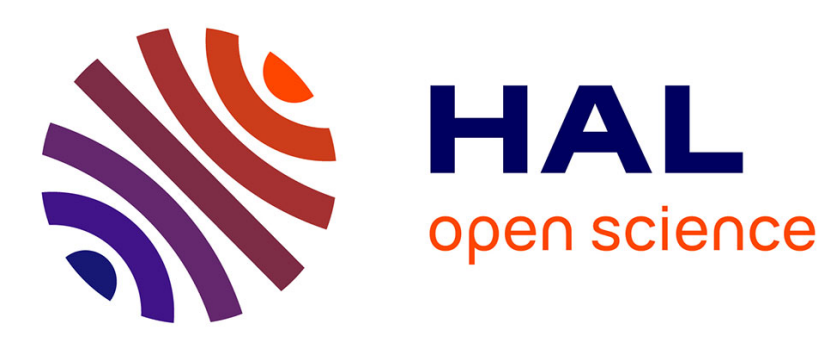

\title{
Micropropagation of two French prune cultivars (Prunus domestica L.)
}

Cristina Baleriola-Lucas, Michael G. Mullins

\section{To cite this version:}

Cristina Baleriola-Lucas, Michael G. Mullins. Micropropagation of two French prune cultivars (Prunus domestica L.). Agronomie, 1984, 4 (5), pp.473-477. hal-00884661

\section{HAL Id: hal-00884661 \\ https://hal.science/hal-00884661}

Submitted on 1 Jan 1984

HAL is a multi-disciplinary open access archive for the deposit and dissemination of scientific research documents, whether they are published or not. The documents may come from teaching and research institutions in France or abroad, or from public or private research centers.
L'archive ouverte pluridisciplinaire HAL, est destinée au dépôt et à la diffusion de documents scientifiques de niveau recherche, publiés ou non, émanant des établissements d'enseignement et de recherche français ou étrangers, des laboratoires publics ou privés. 


\title{
Micropropagation of two French prune cultivars (Prunus domestica L.)
}

Cristina BALERIOLA-LUCAS \& Michael G. MULLINS

Department of Agronomy and Horticultural Science, University of Sydney, N.S.W., 2006, Australia

Phloroglucinol (1,3,5-trihydroxybenzene, PG, $\left.162 \mathrm{mg} \mathrm{l}^{-1}\right)$ was an essential component of media (MurashigeSkoog (MS) containing benzyladenine, $1.0 \mathrm{mg} \mathrm{l}^{-1}$ and $\gamma$-indolebutyric acid (IBA), $0.1 \mathrm{mg} \mathrm{l}^{-1}$ ) for establishment and growth of proliferating shoot cultures of "Commune d'Agen" and "d'Ente 707" prunes. Addition of PG (162 mg $\left.1^{-1}\right)$ to the medium ((MS) containing indole-3-acetic acid (IAA) or $\alpha$-naphthaleneacetic acid (NAA) or IBA, each at $1.0 \mathrm{mg} \mathrm{l}^{-1}$ ) was also required for formation of adventitious roots in vitro by microcuttings. Cultures $\left(23 \pm 2{ }^{\circ} \mathrm{C}\right)$ did not grow if the photoperiod exceeded $12 \mathrm{~h}$. Microcuttings formed roots only after their parent shoot cultures had been conditioned by 4 subcultures, each of one month. Thereafter, rooting capacity increased with subculture. Up to $90 \%$ of microcuttings from subculture 7 formed roots when cultured on media containing both IAA $\left(1.0 \mathrm{mg} \mathrm{l}^{-1}\right)$ and PG $\left(162 \mathrm{mg}^{-1}\right)$. Establishment of own-rooted plants under glasshouse conditions was more difficult with "Commune d'Agen" $(20 \%)$ than with "d'Ente 707 " $(70 \%)$. Micropropagation of these prune cultivars is discussed in relation to plant propagation and plant improvement .

Additional key words : Micropropagation, French prune, d'Ente 707, d'Agen, adventitious roots in vitro, phloroglucinol.

\begin{abstract}
Micropropagation de deux variétés françaises de prunier (Prunus domestica $L$ ).
Le phloroglucinol (1,3,5-hydroxybenzène ; $\mathrm{PG} ; 162 \mathrm{mg} 1$ 1) est un constituant indispensable du milieu de culture (M.S. plus benzyladénine $1.0 \mathrm{mg} \mathrm{l}^{-1}$ et acide $\gamma$-indole butyrique (AIB) $0,1 \mathrm{mg} \mathrm{l}^{-1}$ ) pour l'établissement et la prolifération de bourgeons axillaires des variétés "Commune d'Agen " et d'" Ente 707 ". L'addition de PG (162 $\mathrm{mg}^{-1}$ ) au milieu (M.S. complété soit par l'AIB, $1,0 \mathrm{mg} \mathrm{l}^{-1}$ soit par l'acide indole acétique (AIA) $1,0 \mathrm{mg} \mathrm{l}{ }^{\prime}$ soit par l'acide $\alpha$-naphtalène acétique (ANA) $1,0 \mathrm{mg} \mathrm{l}^{-1}$ ) est aussi nécessaire pour la formation in vitro de racines adventives à partir de microboutures. Les cultures (placées à $23 \pm 2{ }^{\circ} \mathrm{C}$ ) ne se développent pas si la photopériode excède $12 \mathrm{~h}$. Les microboutures forment des racines seulement après un conditionnement des tiges-mères par 4 subcultures d'un mois chacune. Ensuite, le rendement d'enracinement augmente avec les subcultures; après 7 subcultures, la fréquence des boutures formant des racines sur milieu M.S. plus PG $162 \mathrm{mg} \mathrm{I}^{-1}$ et AIA 1,0 mg l ' peut atteindre $90 \mathrm{p}$. 100. L'établissement en serre des vitroplants enracinés est plus difficile avec la variété "Commune d'Agen» $(20$ p. 100) qu'avec « d'Ente 707 » 70 p. 100). La micropropagation de ces variétés de prunier est replacée dans le contexte général de la multiplication et de l'amélioration des plantes.
\end{abstract}

Mots-clés additionnels : Micropropagation, prunier français, d'Ente 707, d'Agen, racines adventives in vitro, phloroglucinol.

\section{INTRODUCTION}

Most of the commercially important cultivars of pome and stone fruits are difficult to root from cuttings and are usually propagated by budding onto clonal or seedling rootstocks. With several scion cultivars of apples (LANE, 1978 ; JONES et al., 1979 ; ZIMMERMANN \& BROOME, 1980 ; SRISKANDARAJAH \& MULLINS, 1981), pears (SINGHA, 1980) and various Prunus (TABACHNIK \& KESTER, 1977 ; JONES \& HOPGOOD, 1979 ; CHANCEL et al., 1980) own-rooted trees have been produced by micropropagation in vitro. In this procedures buds are cultured on cytokinin-enriched media to induce the outgrowth of many axillary shoots. These shoots are then made into microcuttings and are stimulated to form adventitious roots by culture on media containing auxins. The present report concerns the regeneration of ownrooted plants of two cultivars of French prune, d'Agen and the d'Ente (I.N.R.A. selection 707), plants which are known to be especially difficult to propagate from cuttings. 
Special attention was given to two factors: (i) effects of phloroglucinol, a phenolic additive which promotes root formation in microcuttings of some fruit plants (JONES \& HATFIELD, 1976) but not others (ZIMMERMANN \& BROOME, 1980) and (ii) effects of photoperiod and prolonged subculture, treatments which promote root formation in vitro in difficult-toroot cultivars of apple (SRISKANDARAJAH et al., 1982).

\section{MATERIALS AND METHODS}

Three-year-old container-grown mother trees of the common d'Agen prune and of the I.N.R.A. selection, d'Ente 707 (Prunus domestica L.), were provided by the Fruit Variety Foundation, Biological and Chemical Research Institute, NSW Department of Agriculture, Rydalmere, NSW. The mother trees were grown in the glasshouse and were pruned repeatedly to provide supplies of leafy shoots. The unlignified portions of these shoots were made into single node cuttings and the explants were surface sterilized by standard procedures. The basal medium for culture establishment was that of MURASHIGE \& SKOOG (1962, MS-medium). Additives included benzyladenine (BA, $\left.1.0 \mathrm{mg} \mathrm{l}^{-1}\right), \gamma$-indolebutyric acid (IBA, $0.1 \mathrm{mg} \mathrm{l}^{-1}$ ) and phloroglucinol (PG, $162 \mathrm{mg} \mathrm{l}^{-1}$ ).

The medium contained sucrose $(3 \% \mathrm{w} / \mathrm{v})$ and was solidified with agar $(0.8 \% \mathrm{w} / \mathrm{v})$. The $\mathrm{pH}$ was adjusted to 5.5 before autoclaving. Cultures were grown at $23 \pm 2{ }^{\circ} \mathrm{C}$ and illuminated $(12,16$ or $24 \mathrm{~h})$ by cool white fluorescent lamps (Osram QS). The irradiance at the level of the explants was 7-15 $\mathrm{Wm}^{-2}$. Subcultures were made at 4-weekly intervals. Axillary shoots from the initial cultures were made into microcuttings $(20 \mathrm{~mm})$ which were either subcultured to produce further generations of axillary shoots or treated to induce roots. For rooting the microcuttings were grown either on filter paper bridges in test tubes $(25 \mathrm{~mm})$ with half-strength MS-medium containing IBA (0.2-3.0 $\left.\mathrm{mg} \mathrm{I}^{-1}\right)$ and PG (162 $\left.\mathrm{mg} \mathrm{l}^{-1}\right)$ or with an agar-based medium $(0.8 \% \mathrm{w} / \mathrm{v})$ supplemented with mixtures of $\mathrm{PG}\left(162 \mathrm{mg} \mathrm{1}^{-1}\right)$ and one of the following auxins $\left(1.0 \mathrm{mg} \mathrm{l}^{-1}\right)$ : IBA, indole-3-acetic acid (IAA), or $\alpha$-naphthaleneacetic acid (NAA). For establishment of plants under glasshouse conditions, the rooted microcuttings were planted into propagation tubes $(80 \times 25 \mathrm{~mm})$, containing a pasteurized mixture of peat and perlite $(1: 3)$. The propagation tubes were kept initially in trays covered by transparent polyurethane film so as to maintain a high humidity. These plants, which were grown under the same conditions of light and temperature as for micropropagation, were ready for transfer to normal glasshouse conditions after 3 weeks.

\section{RESULTS}

\section{A. Shoot growth : requirement for phloroglucinol (PG)}

With all treatments, bud burst occurred after one week but elongation of the main shoot and production of axillary shoots occurred only in media containing both $\mathrm{BA}$ and PG. In the absence of PG the initial explants produced a rosette of leaves (fig. 1A) which subsequently turned brown and died. In subcultures, as in the initial culture, the emergence and elongation of leafy shoots was dependent upon the presence of phloroglucinol.

\section{B. Shoot growth : effects of culture environment and subculture}

Cultures grew weakly and became chlorotic in long photoperiods $(16 \mathrm{~h})$ or under continuous illumination. The optimum photoperiod for shoot growth was $12 \mathrm{~h}$. Vigorous growth was restored when chlorotic plants grown under long-day conditions were transferred to a $12 \mathrm{~h}$ photoperiod. Cultures incubated at $23 \pm 2{ }^{\circ} \mathrm{C}$ produced greater numbers of axillary shoots than those incubated at $26 \pm 2{ }^{\circ} \mathrm{C}$. In most cultures a single extension shoot was produced by the initial explant. Production of axillary shoots commenced at the 2nd subculture and rose to a maximum after 3 or 4 subcultures. There was considerable variation among explants in total numbers of axillary shoots and means varied from 6-9 (table 1, fig. 1B).

\section{Formation of adventitious roots by microcuttings and plant establishment}

Microcuttings from the initial explants and from the first 4 subcultures could not be made to form adventitious roots. Root formation first occurred in material from the 5th subculture, i.e. after 6 months of culture in vitro (fig. $1 \mathrm{C}$ ). In subsequent subcultures there was a progressive increase in the percentage of microcuttings which formed roots (table 2). At the 10th subculture, and thereafter, it was observed that explants produced adventitious roots while growing in the shoot proliferation medium in the presence of BA $(1.0 \mathrm{mg}$ $1^{-1}$ ).

Adventitious roots were formed only when microcuttings from the 5th and subsequent subcultures were grown on agar-based medium (half-strength MS) containing PG. Microcuttings did not form roots in the absence of PG or if grown on filter-paper bridges with liquid medium. The addition of an auxin, IBA, IAA or NAA $\left(1.0 \mathrm{mg} \mathrm{l}^{-1}\right)$, to cultures containing PG caused a marked increase in the proportion of microcuttings which formed roots and in the numbers of roots per microcutting (table 2). When supplied at a higher concentration $\left(3 \mathrm{mg} \mathrm{l}^{-1}\right)$ each of these auxins promoted

TABLE 1

Production of axillary shoots in vitro by explants of d'Ente prune. Production in vitro de tiges axillaires à partir d'explants de la variété de prunier d'Ente.

\begin{tabular}{ccc} 
Subculture No. $\left({ }^{*}\right)$ & No. Explants & Mean Shoots/Explant \\
\hline 2 & 30 & $2.7 \pm 0.9$ \\
3 & 30 & $5.9 \pm 1.9$ \\
4 & 30 & $9.6 \pm 6.4$ \\
5 & 30 & $7.6 \pm 3.4$ \\
6 & 30 & $7.3 \pm 2.1$
\end{tabular}

(*) Duration of each subculture : one month.

(**) Recorded after one month. 

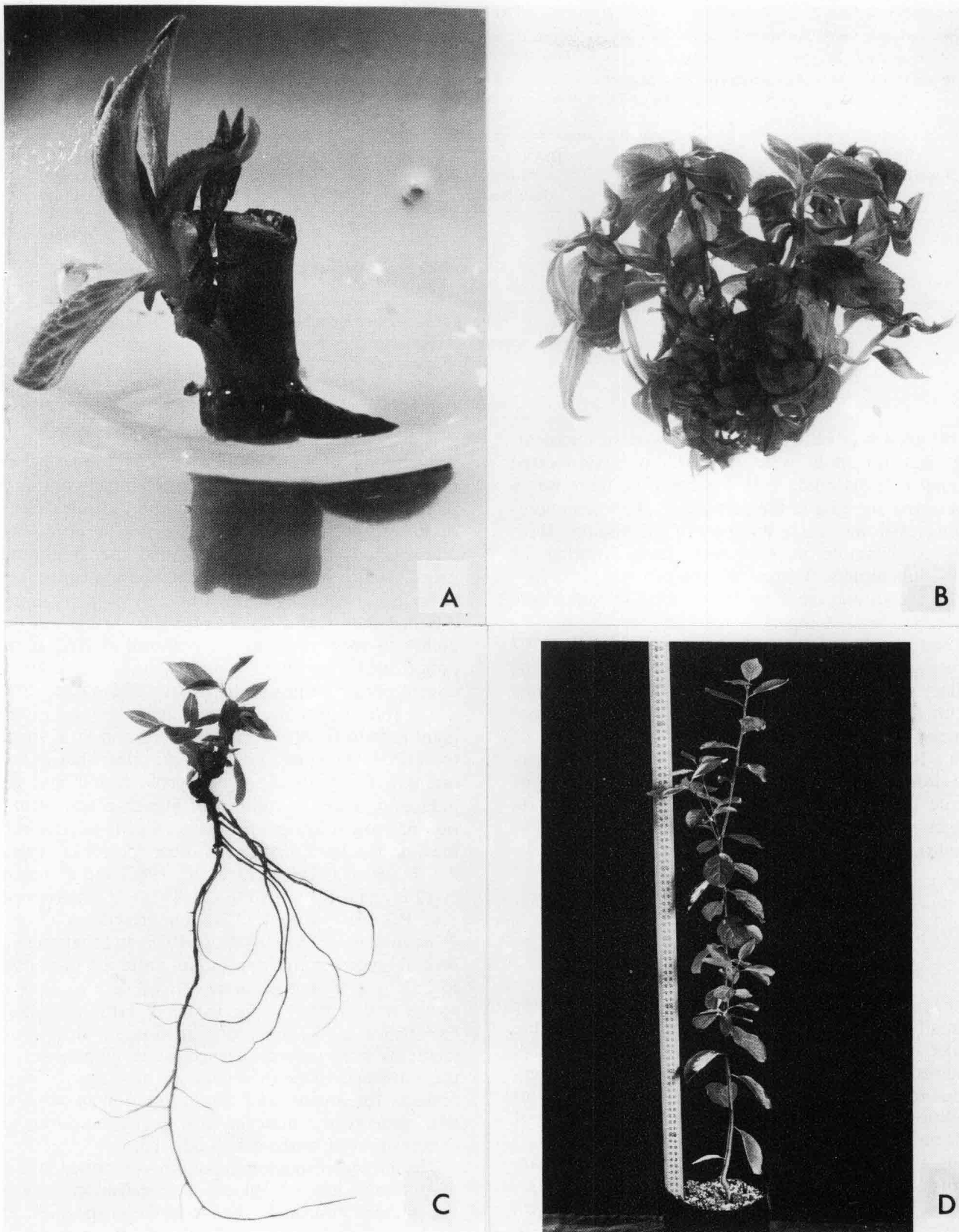

Figure 1A

Nodal explant of d'Ente prune cultured in absence of $P G$. Explants produced only a rosette of leaves ( $\times 4.68)$.

Explant provenant de bourgeon axillaire de prunier d'Ente, cultivé en absence de PG. L'explant produit uniquement une rosette de feuilles $(\times 4,68)$.

\section{Figure 1B}

Proliferation of axillary shoots by a subcultured explant of d'Ente prune $(\times 1.7)$.

Prolifération de bourgeons axillaires par subcultures d'un explant de prunier d'Ente $(\times 1,7)$.

Figure 1C

Rooted microcutting of d'Ente prune $(\times 0.71)$.

Microbouture enracinée de prunier d'Ente $(\times 0,71)$.

Figure 1D

Own-rooted tree of d'Ente prune produced by micropropagation $($ Scale $=1 \mathrm{~m})$. Photographed 2 months after removal of rooted microcutting from the culture vessel.

Prunier d'Ente obtenu par micropropagation (échelle $=1 \mathrm{~m}$ ), photographié 2 mois après le transfert de la microbouture enracinée. 
TABLE 2

Adventitious root formation in vitro in the d'Ente prune : effects of subculture and auxins on rooting of microcuttings grown on inedia containing phloroglucinol $\left(^{*}\right)$.

Formation in vitro de racines adventives chez, le prunier d'Ente: Effets des subcultures et des auxines sur l'enracinement de microboutures cultivées en milieu contenant du phloroglucinol ${ }^{*}$ ).

\begin{tabular}{|c|c|c|c|c|c|c|c|c|}
\hline \multirow{2}{*}{$\begin{array}{c}\begin{array}{c}\text { Origin } \\
\text { of microcutting : } \\
\text { Subculture No. }\left(^{* *}\right)\end{array} \\
1-4\end{array}$} & \multicolumn{2}{|c|}{$\begin{array}{c}\text { Control } \\
\text { \% Rooted }(* * *) \\
\text { Mean No. roots }(* * *)\end{array}$} & \multicolumn{2}{|c|}{$\begin{array}{c}\text { IBA }\left(1.0 \mathrm{mg} \mathrm{I}^{-1}\right) \\
\% \text { Rooted } \\
\text { Mean No. roots }\end{array}$} & \multicolumn{2}{|c|}{$\begin{array}{c}\text { NAA }\left(1.0 \mathrm{mg} \mathrm{l}^{-1}\right) \\
\% \text { Rooted } \\
\text { Mean No. roots }\end{array}$} & \multicolumn{2}{|c|}{$\begin{array}{c}\text { IAA }\left(1.0 \mathrm{mg} \mathrm{l}^{-1}\right) \\
\% \text { Rooted } \\
\text { Mean No. roots }\end{array}$} \\
\hline & 0 & 0 & 0 & 0 & 0 & 0 & 0 & 0 \\
\hline 5 & 16 & $1.6 \pm 0.8$ & 53 & $1.8 \pm 1.0$ & 30 & $1.8 \pm 0.8$ & 72 & $2.3 \pm 1.2$ \\
\hline 6 & 10 & $1.3 \pm 0.7$ & 60 & $2.1 \pm 0.9$ & 45 & $2.3 \pm 0.7$ & 82 & $2.4 \pm 0.7$ \\
\hline 7 & 40 & $1.2 \pm 0.9$ & 75 & $2.5 \pm 0.9$ & 60 & $4.0 \pm 0.8$ & 90 & $2.7 \pm 0.8$ \\
\hline
\end{tabular}

$\left(^{*}\right) 162 \mathrm{mg} \mathrm{1}^{-1} ;\left(^{* *}\right)$ Duration of each subculture : one month ; $\left(^{* * *}\right)$ Recorded after one month.

the outgrowth of callus from the bases of the microcuttings but no roots were formed. In auxin-treated (1.0 $\left.\mathrm{mg} \mathrm{l}^{-1}\right)$ material, as in the controls, there was a progressive increase in the percentage of rooted microcuttings with increasing numbers of subcultures. With IAA, for example, no roots were formed during the first 4 subcultures. Thereafter, the percentage of rooted microcuttings rose to 90 at the 7 th subculture (table 2).

The responses of explants of d'Agen and d'Ente 707 were essentially similar with respect to production of axillary shoots and to formation of adventitious roots but there was a pronounced and consistent difference between the cultivars in the ease of establishment of plants from rooted microcuttings (fig. 1D). The success rate in establishing container-grown plants of d'Ente 707 was approximately $70 \%$ but the common d'Agen was much more difficult to establish $(20 \%$ success)

\section{DISCUSSION}

In French prune, as in some other species which are normally difficult to root from cuttings, aseptic culture can be used to condition the plant material so that it acquires an enhanced capacity for formation of adventitious root primordia. In the present experiments this conditioning process involved prolonged subculture of buds on a cytokinin-enriched medium (BA, $1.0 \mathrm{mg} \mathrm{l}^{-1}$ ) so as to produce successive generations of axillary shoots. These shoots, when made into microcuttings, showed a progressive increase in their ability to form roots with increasing numbers of subcultures (table 2). A similar response has been found in the micropropagation of apple cultivars (SRISKANDARAJAH et al., 1982). Here, the effect of long-term subculture was to cause a progressive reduction in the endogenous levels of abscisic acid (SRISKANDARAJAH, 1983) and gibberellinlike compounds (TAKENO et al., 1982), substances which are known to inhibit the formation of adventitious root primordia when applied exogenously. Similar changes in endogenous hormones may lead to the enhancement of root formation in French prune but this has yet to be investigated.
Research with apple cultivars has shown that improved rooting of microcuttings occurs primarily with material which has been subcultured under continuous illumination (SRISKANDARAJAH et al., 1982). Cultures of French prune, however, could not be grown with photoperiods in excess of $12 \mathrm{~h}$ and the conditioning process which leads to root formation in prunes seems to be less affected by light. A notable property of conditioned shoots of d'Agen and d'Ente prune was their ability to form roots in the presence of BA, a compound which normally inhibits the formation of adventitious root primordia (SMITH \& THORPE, 1975).

The role of phenolic compounds in the regulation of plant growth in vitro is controversial and little understood (POESSEL et al., 1982) but it is clear that PG was essential for both the shoot proliferation and root induction phases in cultures of French prune. Promotion of growth in vitro by inclusion of phenolics in the medium has been reported in other species of Prunus, e.g. P. persica (CHANCEL et al., 1980) and $P$. insititia cv "Pixy" (JONES 8 HOPGOOD, 1979). It is noteworthy that PG was without effect on growth in vitro of $P$. avium (JONES \& HOPGOOD, 1978) and that there are several reports in the literature of variation in response to $\mathrm{PG}$ by differing genotypes of apple e.g. ZIMMERMANN \& BROOME (1980), JAMES \& THURBON (1981). Experience in the micropropagation of fruit crops, including work with the French prune, emphasises that the individual species and cultivars have specific requirements for growth and root formation in vitro and that general recommendations for procedures and composition of media are ill-advised.

The micropropagation procedures described here are of potential interest for plant propagation provided that there is no genetic change in the propagules. The fidelity of reproduction of the genotypes concerned has yet to be tested by field experiment and it would be premature to conclude that micropropagation is suitable for clonal multiplication of d'Agen and d'Ente prunes. Of equal interest is the possibility that micropropagation, involving prolonged subcultures with BA and PG, leads to horticulturally-useful variation within prune cultivars. This possibility is being investigated. 


\section{ACKNOWLEDGEMENT}

This research was supported by the Dried Fruits Research Committee, Commonwealth Department of Primary Industry, Canberra, ACT.

\section{REFERENCES}

Chancel L. M., Machiex J., Jonard R., 1980. Les conditions du microbouturage in vitro du pêcher (Prunus persica Batsch) : Influences combinées des substances de croissance et de divers composes phénoliques. Physiol. Veg., 18, 597-608.

James D. J., Thurbon I. J., 1981. Phenolic compounds and other factors controlling rhizogenesis in vitro in the apple rootstocks M9 and M26. Zeitschr. Pflanzenphysiol., 105, 11-20.

Jones O. P., Hatfield S. G. S., 1976. Root initiation in apple shoots cultured in vitro with auxins and phenolic compounds. J. Hortic. Sci., 51, 495-499.

Jones O. P., Hopgood M. E., 1979. The successful propagation in vitro of two rootstocks of Prunus : the plum rootstock "Pixy " $(P$. insititia) and the cherry rootstock $\mathrm{F} 12 / 1$ (P. avium). J. Hortic. Sci., 54, 63-66.

Jones O. P., Pontikis C. A., Hopgood M. E., 1979. Propagation in vitro of five apple scion cultivars. J. Hortic. Sci., 54, 155-158.

Lane W. D., 1978. Regeneration of apple plants from shoot meristem tips. Plant Sci. Letters, 13, 281-286.

Murashige T., Skoog F., 1962. A revised medium for rapid growth and bioassays with tobacco tissue cultures. Physiol. Plant., 15, 473-497.

Poessel J.-L., Machiex J.-L., Chancel L. M., 1982. Importance physiologique des composés phénoliques chez les arbres fruitiers : Applications au microbouturage in vitro. In : $2^{e}$ Coll. sur les Recherches Fruitières, Bordeaux, 1982, 61-71.
Singha S., 1980. In vitro propagation of Sekel pear. In : Proc. Conf on nursery production of fruit plants through tissue culture : applications and feasibility. R. H. ZIMMERMANN ed., USDA, ARR-NE$11,59-63$.

Smith D. R., Thorpe T. A., 1975. Root initiation in cuttings of Pinus radiata. 1I. Growth regulator interactions. J. Exp. Bot., 26, 193-201.

Sriskandarajah S., 1983. PhD thesis (unpublished), University of Sydney.

Sriskandarajah S., Mullins M. G., 1981. Micropropagation of the "Granny Smith" apple : factors affecting root formation in vitro. $J$. Hortic. Sci., 56, 71-76.

Sriskandarajah S., Mullins M. G., Nair Y., 1982. Induction of adventitious rooting in vitro is difficult to propagate cultivars of apple. Plant Sci. Letters, 24, 1-9.

Tabachnik L., Kester D. E., 1977. Shoot culture for almond and almond-peach hybtid clones in vitro. HortScience, 12, 545-547.

Takeno K. K., Taylor J. S., Sriskandarajah S., Pharis R. P., Mullins M. G., 1982. Endogenous gibberellin-like and cytokininlike substances of apple (M. pumila) in relation to adventitious root formation. Plant Physiol., (Suppl.), 69, 23.

Zimmermann R. H., Broome O. C., 1980. Apple cultivar micropropagation. In : Proc. Conf. on nursery production of fruit plants through tissue culture: applications and feasibility. $\mathrm{R} . \mathrm{H}$. ZIMMERMANN ed., USDA, ARR-NE-11, 54-58. 